\title{
Assessment of prebiotic potentials in selected leaf meals of high dietary fibre on growth performance, body composition, nutrient utilization and amylase activities of a tropical commercial carp fingerlings
}

\begin{abstract}
The performance of selected leaf meals of high dietary fibre in the feed of a tropical commercial carp, hybrid lemon fin barb (Barbonymus gonionotus $q \times$ Hypsibarbus wetmorei §) was evaluated in a 56-day feeding trial. The tropical carp juveniles $(9.43 \pm 0.05 \mathrm{~g})$ were randomly stocked in $60-\mathrm{L}$ aquaria at 15 fish per aquarium. Five isonitrogenous and isocaloric diets ( $30 \%$ crude protein, $17 \mathrm{~kJ} / \mathrm{g}$ gross energy) containing no leaf meal and $10 \%$ napier grass (Pennisetum purpureum), alfalfa (Medicago sativa), water spinach (Ipomea aquatica) and Gliricidia sepium leaf meals were formulated and tested. Three aquaria were randomly assigned to each experimental diet. The results showed that fish-fed diets containing leaf meals showed superior growth performance and body composition which was better than those fed control diet. The leaf meal-treated groups also had higher values of protein, lipid, energy retention and production of digestive enzymes amylase. Conclusively, the results indicated that leaf meal fibre provided better performance showing the inherent prebiotic effect of the utilization of these leaf meal in hybrid lemon fin barb.
\end{abstract}

Keyword: Amylase activities; Dietary fibre; Growth performance; Hybrid lemon fin barb; Leaf meals 